\title{
AMERICAN ELECTION DISCOURSE: IMAGE-BUILDING AS A MEANS OF MANIPULATION
}

\author{
IRINA ANASHKINA ${ }^{1}$ \\ ANASTASYA SOROKINA \\ Mordovian State University, Faculty of Foreign Languages, \\ English Department, \\ Saransk, Russian Federation
}

U fokusu ovog istraživanja su metode skrivenog uticaja u sferi političkog diskursa, koja se tiču fenomena jezičke manipulacije. Postoji veliki broj načina u sferi jezičke manipulacije koji se po svojoj prirodi razlikuju. Ovaj rad uzima u obzir "sliku" kao način kontrolisanja naše svesti i ponašanja. Studije iz ovog domena bave se stvaranjem slike, a poznato je da se one koriste da bi se stvorila idealna slika o nekoj osobi. U političkom diskursu ta osoba je političar u potrazi za moći. U ovom članku, slike su podeljene $u$ dve grupe: one koje su pozajmljene i one koje su integralni deo ličnosti političara. U članku se sumiraju i objašnjavaju najpopularnije i najefektivnije "pozajmljene" slike.

Ključne reči: diskurs, manipulacija, slika, komunikacija, komunikativne namere, kriterijumi procene.

\section{INTRODUCTION}

An approach to politics in the context of the Humanities presents a multipleaspect phenomenon which has a complex ontological structure and consists of a number of concepts based on various sociocultural and ideological orientations (Duka 2004: 34-35). All of these concepts assume the mass consciousness manipulation which is carried out by means of special methods in all kinds of communications: visual, verbal, mythological, etc. One of the many widespread manipulation ways is considered to be the transfer of attention to another object, which may completely eclipse an actual image (Pocheptsov 2009: 141). This example represents the most effective type of the message in the conditions of time and information deficiency (Pocheptsov 2003: 116).

1 Kontakt podaci (Email): anashkina_irina@mail.ru 
This article deals with the problem of the verbal construction of a politician's image. Image construction is considered to be one of the most effective ways of establishing a communication control within the framework of an election discourse. The purposes of the work can be formulated as the following: 1) to describe an image as a means of manipulation of the public opinion, 2) to find out the ways of image-building, 3) to enumerate the most widespread images used by politicians, 4) to prove the relevance of some images to the voters' expectations. The research included two stages: the firstwork with two groups of informants -American- and Russian-cultured representatives, and the second - discourse analysis. The discourse samples are drawn from B. Obama and H. Clinton's election campaign and other political performances of these politicians.

\section{DISCOURSE AS A UNIQUE SPHERE OF INFLUENCE}

According to G. G. Pocheptsov, who has devoted some of his works to image studies, any person is bound to convey certain non-verbal information within their communicational behavior. It is well-known that images may be built verbally (Pocheptsov 2003: 310). Verbal communication dominates any sphere of human activity and is found in a special sphere of language existence - discourse.

The concept of discourse appeared when linguistic research left the sentence boundaries. From the point of view of linguistics, discourse is a complex unit consisting of a sequence of semantically linked sentences (Borbotko 2009: 8). Discourse is also viewed as a crucial segment of man's life "in a language", which Gasparov calls the language existence: "Any language usage - no matter whether it is a highly valued speech continuum or a cue in a dialogue - represents a part of a continuously moving stream of human experience. Qualified like this, discourse incorporates and reflects the unique coincidence of circumstances, which it has been created under and for" (Gasparov 1996: 18). These circumstances include: 1) the communicative intentions of the speaker; 2 ) the relationships of the speaker and the addressees; 3 ) every possible "circumstance", significant or casual; 4) the general ideological features and stylistic climate of the whole epoch and the concrete environment and persons, who the message is directly or indirectly addressed to; 5) the genre and stylistic lines of the discourse realization; 6) a set of associations with the previous experience (Gasparov 1996: 18).

We agree with Duka's discourse definition, which suits the aims and the purposes of the paper. The author understands discourse as a unity of speech and thinking, both connected with two global processes: cognition and presentation of the world by the speaker and the addressee. The final aim of any discourse, in the long run, is to achieve influence on the addressee's feelings, thoughts and actions (Duka 2004: 34-35).

Speech communication is, more often than not, viewed as a social intercourse of people within the help of speech means. Referring to this as a socially significant regulation is very important here. The 1960 's research in the field of the addressee's influence produced the theory of speech acts. The speech communication act, considered from the point of view of its orientation on this or that pre-planned effect, can be defined as a psychological influence. In psychology, the effect of speech influence is understood as a change in the recipient's behavior of influence or its emotional 
condition, or its knowledge of the world, or its attitude to these or other world events and realities, i.e. the change of its personal meaning (Petrenko 1997: 37). Sidorov (2008: 62) believes that, in order to fulfill the speech influence successfully, the speaker should realize the semantic field of the recipient at the moment of influence and after it.

Nowadays, discourse analyses presuppose disclosing the communicative intentions, the obvious and hidden ones, texts, contexts and implied senses and therefore include: 1) intention, 2) language, 3) idea, and 4) context (Rusakova 2004: 31-33).

So far, we have been describing any discourse. Now let us proceed to the target discourse - the political one. In this paper, a political discourse is approached to as a structure constituted with meanings that include: 1) political intentions; 2) meaningful codes of different genres of political existence (a diplomatic reception, election and parliamentary debates, etc.) (Rusakova 2004: 31-33).

Political discourse can be subdivided into propaganda, inauguration, terrorist, psychological and election discourse. The latter is located within the period and space of the election campaign and is made up of different speech patterns characterized by extralinguistic factors. The main purpose of a political discourse is to represent the candidate/party in the most attractive and laudatory way.

Political intentions are carried out by means of manipulation, that is the influence on a person's motives. As for the people, they are not always ready and able to assess the degree and the character of the influence (Kuznetsov 2001: 131). Manipulation is usually defined as a type of physiological impact resulting in subconscious arousal of excitement, which usually does not coincide with the actual existing desires of the person (Dotsenko 2003: 9). It aims at the personality psychological structure. The final aim of the manipulator and manipulation is not to be noticed and disclosed by the recipient (Kara-Murza 2009: 6).

Any manipulation is multilateral. Its arsenal includes images, conventions, inertia, the shackles of habit, etc. (Kopnina 2007: 8). The addressee takes the message without any criticism which gives rise to quite definite illusions and falsies in its consciousness, and provokes him to do things which are profitable to the manipulator (Bykova 1999: 99). In order to achieve this type of influence, different speech strategies and tactics are used. In our work, the manipulative impact of images created by politicians is examined at some length.

\section{BE LIKE THEY WANT YOU TO BE}

The main point for the image to be a powerful means of impact on mass consciousness is that mass consciousness is open to such a communicative unit like image (Kondratyev \& Abramov 2006: 127). A politician's image is created on purpose and in order to achieve certain aims (Egorova-Gantman \& Pleshakov 1999: 5).

Image has a certain structure and it is constructed according to the following rules: a) defining the audience's requirements, b) formulating the character's catch of the image, and c) using different codes and contexts (verbal, eventful, contextual, etc.) Our work is performed on the American election discourse, so it was very important to find out the criteria of assessment existing in the minds of American representatives. Therefore, four representatives of the American culture were interviewed personally 
and twenty-four Americans examined via the Internet survey. In addition, we felt the results of the research might be more interesting if a comparison with Russian representatives was carried out. That is why the other group of informants was represented by teachers and students of the Mordovian State University and comprised forty people. The candidate's most important characteristics were singled out by the Russian and American informants. Their preferences are presented in a decreasing pattern (where 14 is the least preferable feature, and 1 is the most preferable one). The results of the questionnaire are the following:

Group 1 (American)

1. Adherence to principles

2. Erudition

3. Leadership ability

4. Intellect

5. Kindness

6. Honesty

7. Determination

8. Sociability

9. Vitality

10. Obligeness

11. Young age

12. Disinterestedness

13. Decency

14. Rigidity
Group 2 (Russian)

1. Intellect

2. Decency

3. Honesty

4. Obligeness

5. Leadership ability

6. Determination

7. Erudition

8. Kindness

9. Disinterestedness

10. Adherence to principles

11. Vitality

12. Sociability

13. Rigidity

14. Young age

The most interesting fact is that the American informants have put "adherence to principles" in the first place. "Leadership ability" is highly appreciated by the American culture representatives, as well. Thus, this quality comes to the fore. It is also interesting that "decency" and "disinterestedness" are not considered by Americans as integral attributes of a successful politician, whereas the research among Russian-speaking informants indicates their importance.

\section{THE IMAGE ANALYSIS OF THE CANDIDATE'S PERSONALITY}

For the purpose of analyzing the image of a candidate we chose the political performances of Mr. Obama and Mrs. Clinton in the USA 2008 presidential elections and studied their speeches as presented on several relevant websites listed in the references section.

The first image employed by these candidates was the "mother image". During the election campaign, Mrs. Clinton focuses the attention of her potential voters on the fact 
that she is a good mother. This idea is put into words by her daughter Chelsea: "... I'm so blessed to have her as the best mom I could imagine - at 8, 18, and 28" (DD)2. There is also a remark from one lady working in Mrs. Clinton's team. She also mentions Mrs. Clinton's merits both as a person and as a mother: "... I knew her first as a mother and a neighbor... I grew up surrounded by strong women public servants - Hillary, fighting to improve things like education and health care...". She draws the attention of the electorate to the most important part in every person's life - the children: "We need to get our country back on track for all these children who are trying to grow up...". She keeps on describing her as a strong, fearless character, capable of taking care of their children's future: "...Extraordinary intelligence, wisdom, strength, compassion, and the heart of a lion. An unwavering commitment to facing and solving tough problems, and 35 years of experience that inform her every step of the way... I would do anything for Hillary, this one's for those girls - and everyone else's sons and daughters" (HC).

Mr. Obama also borrows the "mother image" from a lady telling the story about her son who was serving in Iraq: "... she said to me, "I can't breathe. I want to know, when am I going to be able to breathe again?" It is time to let this woman know she can breathe again. It is time to put an end to this war" (B0). Here Mr. Obama acts as a defender of mothers, longing for their children to come back home.

The second widespread image is the "soldier image". Mrs. Clinton's personality is linked with the word "fight". This image is confirmed with some above-mentioned epithets like "unwavering commitment". There is also a story of the photo of a veteran of the Second World War, given to her with an inscription: "To Hillary Clinton, keep fighting for us" (HC). Thanks to the story, in the voters' mind, Mrs. Clinton and this old soldier are united to struggle for their country.

A similar image is created by Mr. Obama. However it pertains to a "hero image". An extract from the Moscow News article is cited as an example: "The American people, who loved John Kennedy, were disappointed when Bill Clinton did not live up to the potential that we envisioned. Following international problems of terrorism, failing wars in Iraq and Afganistan, as well as rife corruption, America longs for a return to Camelot. For some Americans, Barack Obama is this year's designed hero... He is handsome, a brilliant speaker, with charisma..." (MNR).

One more popular image discovered in our research is the "working people image". Mr. Obama makes the best use of it, and as a result we can see the generalized image of the American people, which is represented in the story of Ashley, a young girl whose mother is seriously ill: "She told everyone at the roundtable that the reason she joined the campaign was so that she could help the millions of other children in the country who want and need to help their parents too". Others had different reasons for being with Mr. Obama. At the end of the talk, one African American said: "I am here because of Ashley". (B0). Thus, Mr. Obama implicitly addresses the people who are not interested in politics, urging them to support such people as Ashley.

The third image of manipulation is the "destroyed country image". The candidate assuming office always blames the former president for problems with the government. In his State of the Union Address dated January 27, 2010, B. Obama reminds

2 See Internet Resources for abbreviation explanations. 
the Americans of all the troubles that existed before he took office and mentions the difficulties they are faced with nowadays: "...0ne year ago, I took office amid two wars, an economy rocked by a severe recession, a financial system on the verge of collapse, and a government deeply in debt..." (ABCN). One more favorite image used in the manipulation of someone's consciousness is that of the "enemy image". Mr. Obama regularly mentions the invisible ill-wisher: "... I've been told that our political system is too gridlocked and that we should just put things on hold for a while" or "Now, the House has already passed financial reform ... and the lobbyists are trying to kill it. But we cannot let them win this fight..." (ABCN).

One more interesting moment of the presidential speech is an image of the optimistic, positive reaction of Americans to what he does, their belief in success, captured in an "optimism image". His speech programs people to have a positive attitude to what is happening in the country: "What keeps me going - what keeps me fighting - is that despite all these setbacks, that spirit of determination and optimism, that fundamental decency that has always been at the core of the American people, that lives on. It lives on in the struggling small business owner who wrote to me of his company, "None of us," he said, "...are willing to consider, even slightly, that we might fail." It lives on in the woman who said that even though she and her neighbors have felt the pain of recession, "We are strong. We are resilient. We are American..." (ABCN).

Let us give the idea of image from another angle: the image of a politician as a sum of personal qualities. Here it is necessary to remark that images can be created to discredit a candidate. The politician can be accused of not possessing the qualities he claims to have. During the debates, Mr. Obama answered questions evasively, which raised some doubts about his honesty: "Constrained by a 60-second limit for replies that worked against Obama's speaking style - a very long windup to the pitch - his tendency to generalize meant he did not directly answer some questions. He sounded out of touch" (BCT). Answering the question about al-Qaeda, Obama did not meet the electorate expectations and could not prove that he would ensure the security of the American people. Thereby, his leadership and professional qualities were strongly doubted. After a reference to the botched response to Hurricane Katrina, he said "review how we operate in the event of not only a natural disaster, but also a terrorist attack" (BCT). Mrs. Clinton's answer to this question, on the contrary, was approved. It was the answer of a determined leader capable of making the right decision: "Retaliate," she said. "Focus on those who have attacked us and do everything we can to destroy them". "Take the answer-back measures", she said (BCT).

The next extract of Mr. Obama's speech which begins with the expression "the truth is" highlights his honesty towards his recipients: "But the truth is these steps won't make up for the seven million jobs that we've lost over the last two years" (FOXN). The president's erudition, which was highly appreciated by our informants, is revealed when he talks about innovations: "world's cheapest solar cells or treatment that kills cancer cells but leaves healthy ones untouched", "investments in clean energy", "safe, clean nuclear power plants", "new offshore areas for oil and gas development", "advanced biofuels and clean coal technologies", etc. (GUK). 


\section{CONCLUSION}

Having analyzed all the material above, we came to the conclusion that there is a great number of images used by politicians and their teams which are meant to have a manipulative impact on the electorate and make a significant contribution of any election campaign. The manipulation influence is realized through the discourse disclosing the communicative intentions, the obvious and hidden meanings, texts, contexts and implied senses. The purposefully formed image, or the images borrowed from other people's inventory and involved in the process of image-building are used to create an ideal politician, meeting the voters' requirements.

Ourstudy of the samples of Mr. Obama'sand Mrs. Clinton's election discourse resulted in defining the most popular images that image-makers use: the "mother image", the "soldier image", the "working people image", the "enemy image", the "optimism image", and the "destroyed country image". Referring to characteristics of a politician, image-makers appeal to his or her leadership qualities, determination, erudition which overlaps with intellect and honesty. This conclusion confirms the results of our research in the field of the American election discourse in which the above-mentioned characteristics were considered to be the main ones. There is only one aspect which wasn't confirmed in the candidates' performances, and it is adherence to principles. Meantime it turned out to be the most relevant aspect in electing the president for the Americans surveyed. One more interesting characteristics which failed to meet the voters' expectations was "kindness". None of the presidential aspirants had a tendency to treat favourably either the opponents or the country's condition. The only exception for this tendency is when they speak about their families.

Taking into consideration all the above said it is reasonable to suggest that the candidates' programmes aimed at winning the campaign by telling the people what they want to hear were a success. It also proves the fact that in a political discourse there is a skillfully used method of mass manipulation which helps to produce a desirable effect on the potential voters.

\section{REFERENCES}

Borbotko, V. G. 2009. Discourse formation principles. Moscow: LIBROKOM.

Bykova, 0. N. 1999. Language manipulation. In A. Skovorodnikov (ed.) Russian rhetorical association bulletin. Moscow: Krasnoyarsk, 99-103.

Dotsenko, E. L. 2003. Manipulation physiology. Moscow: MSU.

Duka, 0. G. 2004. Political discourse through the sense field theory. In 0. Rusakova (ed.)

Discourse-Pi: academic and research miscellany. Ekaterinburg: Soyuz, 34-35.

Egorova-Gantman, E. V. \& Pleshakov, K. V. 1999. Political advertising. Moscow: "Nikollo-M". Gasparov, B. M. 1996. Language. Memory. Image. Linguistics of language existence.

Moscow: New literary review.

Kara-Murza, S. G. 2009. Consciousness manipulation. Moscow: Eksmo.

Kondratyev, E. V. \& Abramov, R. N. 2006. Public relations. Moscow: Triksta.

Kopnina, G. A. 2007. Language manipulation. Moscow: Science. 
Kuznetsov, V. F. 2001. Public relations. Moscow: Vakler.

Petrenko, V. F. 1997. The bases of psychosemantics. Smolensk: SGU.

Pocheptsov, G. G. 2009. Imagology. Moscow: Smartbook.

Pocheptsov, G. G. 2003. Comunication theory. Moscow: Smartbook.

Rusakova, 0. F. 2004. Political discourse through the sense field theory. In 0. Rusakova

(ed.) Discourse-Pi: academic and research miscellan. Ekaterinburg: Soyuz, 31-33.

Shepel, V. M. Imagology. 2002. Moscow: Folk education.

Sidorov, E. V. 2008. Discourse ontology. Moscow: LKI.

\section{INTERNET RESOURCES}

ABCN: http://www.abcnews.go.com [06.10.2010]

B0: http://www.baracobama.com [12.09.2010]

BCT: http://www.blogs.chicagotribune.com [03.10.2010]

DD: http://www.thedemocraticdaily.com [12.09.2010]

FOXN: http://www.foxnews.com [06.10.2010]

GUK: http://www.guardian.co.uk [06.10.2010]

HC: http://www.hillaryclinton.com [12.09.2010]

MNR: http://www.moscownews.ru [03.10.2009]

\section{SUMMARY}

\section{AMERICAN ELECTION DISCOURSE: IMAGE-BUILDING AS A MEANS OF MANIPULATION}

This paper is motivated by a number of manipulative strategies used in an election discourse. The methods of hidden influence in the sphere of political discourse were examined in this research. Our interests concern the phenomena of language manipulation. There is a great number of language manipulation tricks that vary in their nature. This article takes into consideration an "image" as a way of controlling our consciousness and behavior. The image studies deal with creating images. These images are used to build an ideal portrait of a person. In political discourse this person is a politician in search for power. Within the boundaries of this article, images were divided into two groups: those which are borrowed and those which are part and parcel of the personality of a politician. The research resulted in revealing the most popular and effective "borrowed" images.

KEYWORDS: discourse, manipulation, image, communication, communicative intentions, estimation criteria. 